\title{
Dystonia in an Adolescent on Risperidone Following the Discontinuation of Methylphenidate: A Case Report
}

\author{
Gulen Guler ${ }^{1}$, Veli Yildirim¹, Meryem Ozlem Kutuk ${ }^{2}$, Fevziye Toros ${ }^{1}$ \\ ${ }^{1}$ Department of Child and Adolescent Psychiatry, Mersin University Medical Faculty, Mersin, ${ }^{2}$ Department of Child and Adolescent \\ Psychiatry, Baskent University Medical Faculty, Adana, Turkey
}

\begin{abstract}
Attention-deficit/hyperactivity disorder (ADHD) is a neurodevelopmental disorder with common comorbidities that include oppositional defiant disorder, conduct disorder, anxiety disorder, and affective disorders. Because of these comorbidities, drug combination treatments and drug-drug interactions are becoming increasingly more frequent. The present case report describes an acute dystonic reaction following the abrupt discontinuation of methylphenidate from a drug regimen with risperidone. The patient experienced acute dystonic reactions on three separate occasions when he forgot to take his methylphenidate medication. The present report informs clinicians about the possible side effects, such as dystonia, when psychostimulant and antipsychotic drug combinations are altered and suggests that the abrupt cessation of stimulants may lead to the development of movement disorders. Therefore, appropriate care is necessary when changing the dose of a drug or abruptly discontinuing a drug from a combination of psychostimulants and antipsychotics.
\end{abstract}

KEY WORDS: Dystonia; Methylphenidate; Antipsychotic agents; Drug combinations.

\section{INTRODUCTION}

The use of atypical antipsychotics in conjunction with stimulants is becoming an increasingly more frequent option for the treatment of attention-deficit/hyperactivity disorder (ADHD) ${ }^{1)}$ However, if the stimulant medication is removed from a treatment regime that includes an atypical antipsychotic agent, it is possible that an acute dystonic reaction (ADR) may occur, albeit rarely. ${ }^{2)}$ Only four cases of dystonic reactions following the interruption of stimulant use during a regimen of a stimulant and an atypical antipsychotic have been reported; the present report is the fifth case. Clinicians must be aware of the possible side effects, including dystonia, when the stimulant component of a psychostimulant and antipsychotic drug combination regimen is changed.

\footnotetext{
Received: October 23, 2014/Revised: December 23, 2014

Accepted: December 31, 2014

Address for correspondence: Gulen Guler, MD

Department of Child and Adolescent Psychiatry, Mersin University Medical Faculty, Ciftlikkoy Campus, Yenisehir-Mersin 33343, Turkey Tel: +90-507-5093592, Fax: +90-3242410092 E-mail:dr.gulen@hotmail.com
}

\section{CASE}

A male patient was referred to our clinic with complaints of hyperactivity, disrespectful behaviors, and contentiousness at 9 years of age. He was born at 37 weeks gestation by elective cesarean section and completed his developmental stages in an appropriate timeframe. He had no family history of psychiatric or physical illness and started primary school at 7 years of age. He learned to read and write during his first year of school, but his teacher complained about his not listening to lessons and talking loudly and arguing with his friends. An evaluation with the Conners Parent and Teacher Rating Scales confirmed the boy's symptoms, and he was diagnosed with ADHD and conduct disorder.

His initial treatment consisted of $27 \mathrm{mg}$ of modified-release methylphenidate (MPH). One month later, the dose of MPH was increased to $36 \mathrm{mg}$, and $0.5 \mathrm{mg}$ of risperidone was added due to his behavior problems. Although the child partially benefited from the treatment, his parents and teachers continued to have complaints about his behavior; specifically that the child was restless and irritable when the impact of MPH was no longer felt. Therefore, the risperidone dose was gradually increased to $3 \mathrm{mg}$ and divided into two doses; his most recent treatment

(c) This is an Open-Access article distributed under the terms of the Creative Commons Attribution Non-Commercial License (http://creativecommons.org/licenses/by-nc/3.0) which permits unrestricted non-commercial use, distribution, and reproduction in any medium, provided the original work is properly cited. 
regimen consisted of $54 \mathrm{mg}$ of $\mathrm{MPH}$ and $3 \mathrm{mg}$ of risperidone. After a long interval using this treatment regimen, the child was admitted to the emergency room with complaints of licking, tongue protrusion, and tension with difficulty closing his mouth. His neurological examination and blood tests, including electrolyte levels, were all in the normal range. Ultimately, it was learned that his symptoms began to appear 6-7 hours after he failed to take his MPH medication. He had always regularly taken both MPH and risperidone until that time, and whenever he forgot his MPH medication, the same complaints recurred. He experienced these behavioral symptoms three times.

\section{DISCUSSION}

ADR is an extrapyramidal symptoms (EPS) characterized by involuntary, transient, or permanent muscular contractions, especially in the head, neck, and face. ${ }^{3)}$ ADR typically manifests within a few days after the initiation of an antipsychotic drug regimen; the risk factors include a young age, male gender, primary psychotic disorder, and previous dystonic reactions. ${ }^{3)}$ In the present case, a patient was a child and male, which were thought to increase the risk of ADR.

MPH results in a downregulation of postsynaptic dopamine receptors via an increase in the amount of dopamine and noradrenaline, particularly of dopamine in the synaptic cleft. ${ }^{4)}$ Conversely, antipsychotics upregulate dopamine receptors by binding to postsynaptic $\mathrm{D} 2$ receptors. Although antipsychotics and MPH have opposite effects on the dopaminergic system, ${ }^{6}$ these drugs are often used in combination for the treatment of ADHD.

The combination of psychostimulant and antipsychotic drugs has been reported to be safe and highly effective for the treatment of aggression in children and adolescents. ${ }^{7,8)}$ However, in the present case, the uncommon occurrence of dystonia as a result of the sudden cessation of MPH during combination therapy with risperidone was reported. Similar cases have been reported including four patients that experienced ADR when the stimulant component was removed from a regimen of antipsychotics and stimulants in combination. ${ }^{9,10)}$ In another case, dystonia developed following a change in the stimulant dose when dextroamphetamine and an antipsychotic were used concurrently. ${ }^{11)}$ Yet another case reported that ADR was associated with an interruption in drug treatment during a regimen which included aripiprazole, a partial agonist of dopamine. ${ }^{2)}$

In the present case, EPS did not develop during con- comitant use of risperidone and MPH; rather, the patient experienced ADR when he did not take the stimulant medication. The patient had taken MPH for 1 month prior to the initiation of risperidone, which raises the question; if the patient had received risperidone from the onset of treatment, would the ADR still have occurred? Dystonia is not an expected side effect of the discontinuation of MPH after the its concurrent use with risperidone for 2 months. A salient issue in this case is that ADR, which is highly likely to emerge in the first few days of antipsychotic treatment, ${ }^{3)}$ was observed after a long treatment interval. However, it is known that the abrupt cessation of stimulant treatment may lead to the development of movement disorders, ${ }^{2,9-11)}$ as in the present case. Moreover, a change in the dose of MPH is related to alterations in metabolic activity in extrapyramidal system components such as the substantia nigra and subtalamica nucleus. ${ }^{12)}$

It is possible that the etiology of acute EPS is associated with the discharge of dopamine in the synaptic cleft or excessive dopaminergic activity which cannot be blocked due to dopaminergic influences on hypersensitive dopamine receptors. ${ }^{13)}$ Amphetamine, cocaine, and MPH have similar mechanisms of action, and amphetamine and cocaine use during antipsychotic treatment is a risk factor for dystonia. ${ }^{14,15)}$ Therefore, when used in combination with antipsychotics, MPH may also increase the risk of ADR. Dystonia developed in a patient when MPH was added to a drug regimen that included aripiprazole. ${ }^{16)}$ In this case, MPH seemed to initiate e EPS instead of preventing it, whereas in the present case, MPH seemed to be protective against EPS.

The precise mechanisms underlying the manifestation of ADR remain unclear. However, the findings of the present case study suggest that it would be beneficial to begin stimulant treatment at a low dose and to slowly and incrementally decrease stimulant doses when they are used in combination with antipsychotics, especially in children and adolescents.

\section{REFERENCES}

1. Tsang K. Drug-induced movement disorders. Med Bull 2008; $13: 4-5$.

2. McLaren JL, Cauble S, Barnett RJ. Aripiprazole induced acute dystonia after discontinuation of a stimulant medication. $J$ Clin Psychopharmacol 2010;30:77-78.

3. Rodnitzky RL. Movement disorder emergencies. In: Roos KL, editor. Emergency neurology. New York:Springer Science Business Media;2012. p.259-283.

4. Findling RL. Evolution of the treatment of attentiondeficit/hyperactivity disorder in children: a review. Clin Ther 2008;30:942-957.

5. Silvestri S, Seeman MV, Negrete JC, Houle S, Shammi CM, 
Remington GJ, et al. Increased dopamine D2 receptor binding after long-term treatment with antipsychotics in humans: a clinical PET study. Psychopharmacology (Berl) 2000;152:174-180.

6. Sabuncuoglu O. Risperidone-to-methylphenidate switch reaction in children: three cases. J Psychopharmacol 2007;21:216-219.

7. Aman MG, Binder C, Turgay A. Risperidone effects in the presencelabsence of psychostimulant medicine in children with ADHD, other disruptive behavior disorders, and subaverage IQ. J Child Adolesc Psychopharmacol 2004; 14:243-254.

8. Findling RL. Dosing of atypical antipsychotics in children and adolescents. Primary Care Companion $J$ Clin Psychiatry 2003;5 Suppl 6:10-13.

9. Benjamin E, Salek S. Stimulant-atypical antipsychotic interaction and acute dystonia. J Am Acad Child Adolesc Psychiatry 2005;44:510-512.

10. Keshen A, Carandang C. Acute dystonic reaction in an adolescent on risperidone when a concomitant stimulant medication is discontinued. J Child Adolesc Psychopharmacol
2007; 17:867-870.

11. Levine JB, Deneys ML, Benjamin S. Dystonia with combined antipsychotic and stimulant treatment. J Am Acad Child Adolesc Psychiatry 2007;46:665-666.

12. Porrino LJ, Lucignani G. Different patterns of local brain energy metabolism associated with high and low doses of methylphenidate. Relevance to its action in hyperactive children. Biol Psychiatry 1987;22:126-138.

13. Işık E, Uzbay T. Antipsikotik ilaçların yan etkileri. In: Işılk E, Uzbay T, editors. Güncel Temel ve Klinik Psikofarmakoloji. Ankara:Golden Medya;2008. p.107-122.

14. Shen YC. Amphetamine as a risk factor for aripiprazoleinduced acute dystonia. Prog Neuropsychopharmacol Biol Psychiatry 2008;32:1756-1757.

15. Duggal HS. Cocaine use as a risk factor for ziprasidoneinduced acute dystonia. Gen Hosp Psychiatry 2007;29:278279.

16. Sharp BW. Cmap ADHD and comorbid aggression algorithm. J Am Acad Child Adolesc Psychiatry 2007;46:1; author reply 1-3. 